\title{
FEASIBILITY OF RAINWATER HARVESTING IN SOLVING WATER CRISIS DHAKA CITY
}

\author{
Shafayet Ahmed ${ }^{1}$, Nazmunnahar ${ }^{2}$ \\ ${ }^{I}$ Corresponding AuthorGraduate Student, Department of Civil and Environmental Engineering, Idaho State \\ University, Idaho,USA. \\ ahmeshaf@isu.edu \\ ${ }^{2}$ Associate Professor, Department of Civil and Environmental Engineering, North South University, Dhaka, \\ Bangladesh. \\ nazmun.nahar@northsouth.edu
}

\begin{abstract}
This paper assesses the feasibility of rainwater harvesting as a solution to the existing water crisis in Dhaka City - a mega city with a population of 15 million. Groundwater is the main source of Dhaka's water supply. To meet the increasing demand, the groundwater table is decreasing at an alarming rate. Dhaka needs to find out otherpotential sources of water. Rivers surrounded by the city would be a solution but due to high pollution, most of those rivers are now out of consideration. In this context, rainwater harvesting could be a potential source of water that will be able to meet a significant part of water demand of the Dhaka city residents. Also a high rainfall rate during the monsoon period is an important factor in this regard. In this study, a six storied high rise building with 80+ residents was investigated. Rainwater harvesting is considered only for the purpose of toilet flushing, washing cloths and house cleaning. In order to understand the social impat of rainwater harvesting, a resident survey was conducted. $88 \%$ of the residents agreed that rainwater harvesting wouldbe an acceptable solution of the present water crisis.
\end{abstract}

Key words: Rainwater Harvesting, High Rise, Groundwater Table, Efficiency Factor.

\section{INTRODUCTION}

Dhaka, the capital of Bangladesh and a mega city of around 15 million people has a serious problem associated with water supply system. Due to significant increase of migrant people towards Dhaka the population is increasing day by day and projected population is 40 million By 2050.The population is increasing but there is no such significant development of the water supply condition in Dhaka city. At present, $87 \%$ of total water demand of Dhaka city is met by groundwater. As a result of rapid urbanization and extreme water demand, groundwater table of Dhaka city is going down at an alarming rate. At present the depletion rate is 2.81 meter/year whichis a serious threat upon the water supply system of Dhaka city and the rate made us to think about the alternative sources of water. Dhaka is surrounded by four major rivers ; Buriganga, Turag, Shitalakkhya and Balu that could be a potential source of water and a permanent solution of present crisis. But careless industrial as well domestic discharge to the rivers worsens the situation. Figure 1 shows the projected consumptive demand and the total anticipated water production between 1990 and 2050. In the long run, there will be significant difference between water demand and production.

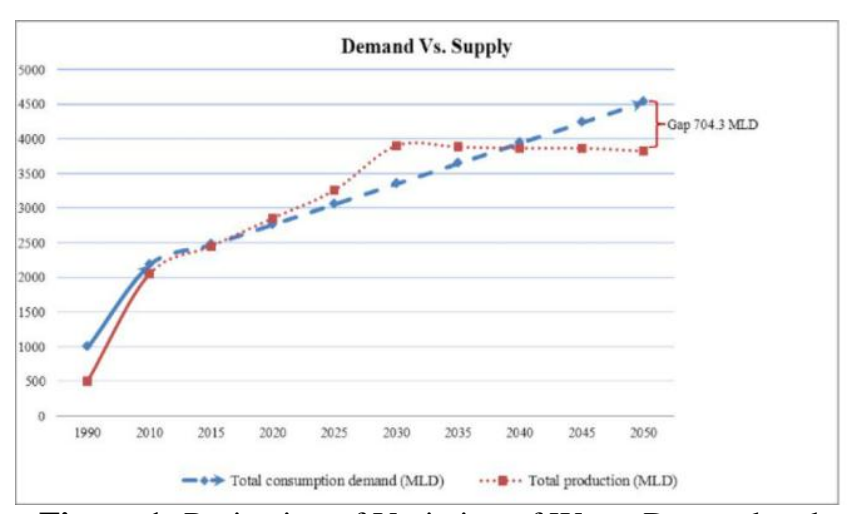

Figure 1: Projection of Variation of Water Demand and Water Supply in Dhaka city.

To solve this problem, rainwater harvesting would be an effective solution. Bangladesh receives a heavy rainfall during monsoon period that can be utilized as a source of water. Most of the time rainwater iscollected through the drainage structures, the quality of rainwaterisdegraded and hence the rainwaterwill no longer beuseable. If rainwater is collected properly, It is possible to partially solve the water crisis of Dhaka city.

\section{METHODOLOGY}

In this study, a six storied residential building located at Mohammadpur area of Dhaka is selected for rainwater harvesting. Collected rainwater will be used mainly for toilet 
flushing, washing cloths and house cleansing. Roof top of the building is used as the catchment area to collect water. To conduct the study, total rainfall of Dhaka city for the year of 2012 is used. The study conducted by calculating the daily water demand by the residents of that building particularly for toilet flushing, washing cloths and house cleansing and calculating the amount of water collected by roof top of the building. From the total collected roof top water, 2 liter/sqm is deducted as first flush and $80 \%$ efficiency factor is considered while calculating the roof yield. Table 1 shows the breakdown of water consumption based on different house holdtasks. For this study, daily water consumption rate of 60 litre/day is used that includes washing clothes, cleaning house and toilet flushing.

\begin{tabular}{|c|c|}
\hline Use & Consumption(l/p/d) \\
\hline Drinking & 5 \\
\hline Cooking & 5 \\
\hline Bathing(including ablution) & $\mathbf{2 0}$ \\
\hline Washing clothes & 10 \\
\hline Washingutensils & $\mathbf{1 0}$ \\
\hline Cleaning house & $\mathbf{3 0}$ \\
\hline Toilet flushing & \\
\hline
\end{tabular}

Table 1: Daily Water Consumption Rate [CSE, 2010]

\section{EXISTING WATER SUPPLY CONDITION IN THE BUILDING}

The building is located at Mohammadpur residential area, a six storied building of total 85 residents. Most of the residents get the water by DWASA central water supply system and there is no significant damage in the pipe connections. For emergency purpose, an over head water tank was built on roof top. The roof area of the building is measured as $6630 \mathrm{ft}^{2}$ or $615.95 \mathrm{~m}^{2}$. The people of that building used to flush toilet around 25 times a day and used to clean house once in a day. Despite using washing machine the residents are used to clean their cloths manually once in a day. Residents of that building has some idea on rainwater harvesting and they appreciate the system of collecting rainwater. Some of them are interested on usage of rainwater as potable drinking water though they emphasize highly on the quality of rainwater for drinking purpose.

\section{RESULT}

The outcome of this study is quite interesting. Harvested rainwater from the roof top of the building savednearly $69 \%$ of total water required by the residents for toilet flushing, house cleansing and washing cloths for the period of AprilAugust. The finding is very encouraging that makes us think about applying rainwater harvesting at a larger scale.

\begin{tabular}{|c|c|c|c|c|}
\hline Month & Rainfall (m) & Roof & Roof Yield & Roof Yield \\
\hline & & Yield $\left(\mathrm{m}^{3}\right)$ & calculating & (L) \\
\hline & & & $80 \%$ & \\
\hline & & & Efficiency & \\
\hline & & & Factor & \\
\hline April & 0.27 & 165.7 & 132.5 & 132551.8 \\
\hline May & 0.14 & 84.4 & 67.5 & 67507.8 \\
\hline & & & & \\
\hline June & 0.17 & 107.8 & 86.2 & 86232.6 \\
\hline July & 0.23 & 139.2 & 111.4 & 111363.2 \\
\hline & & & & \\
\hline August & 0.28 & 173.7 & 138.9 & 138957.7 \\
\hline
\end{tabular}


Table 2: Amount of Roof Yield for the Month of April-August.

\begin{tabular}{|l|l|l|}
\hline Month & Days & Total Demand (L) \\
\hline April & 30 & 153000 \\
\hline May & 31 & 158100 \\
\hline June & 30 & 153000 \\
\hline July & 31 & 158100 \\
\hline August & 31 & 158100 \\
\hline
\end{tabular}

Table 3: Amount of Water Demand for April-August for Toilet Flushing, House Cleansing and Washing Cloths.

\begin{tabular}{|l|l|l|}
\hline Month & Roof Yield (L) & Water Demand (L) \\
\hline April & 132551.8 & 153000 \\
\hline May & 67507.8 & 158100 \\
\hline June & & 153000 \\
\hline July & 86232.6 & 158100 \\
\hline August & 111363.2 & \\
\hline Total & & 158100 \\
\hline
\end{tabular}

Table 4 : Comparison of Roof Yield and Demand.

Total roof yieldis536613.11 Lwhichisroughly69\% of total demand 780300 L.

\section{CONCLUSION AND RECOMMANDATION}

The study is a preliminary assessment of the feasibility of rainwater harvesting technology. Using this technology, a significant portion of water demand of Dhaka city is possible to meet. Rainwater can be used as potable drinking water after necessary treatment. Rainwater harvesting system can be use in large scale implementation such as large commercial, industrial building and even for a cluster of houses.

\section{REFERENCES}

[1].Cox, Wendell. (2009). The Draw of Dhaka. $w w w$.newgeography.com/content/00778-the-drawdhaka.

[2].Uddin, Azim., Baten, Mohammad Abdul. (2011). Water Supply of Dhaka City: Murky Future, The Issue of Access and Inequality.

[3].Appan, A. (2000). A Duel-mode System for Harnessing Roof Water for Non Potable Uses. Urban Water, 1(4), 317-321

[4].Chilton, J.C., Francis, A., Maidment, G.G., Marriot, D., 
\& Tobias, G. (2000). Case Study of Rainwater Recovery System in a Commercial Building with Large Roof. Urban Water, 1(4), 345-354.

[5].Choudhury, I. (2007). Rainwater Harvesting. URL http://www.tamu.edu/classes/cosc/choudhury/rain/sld001 .htm.

[6].Fewkes, A. (2000). Modeling the Performance of Rainwater Collection System : Towards a GeneralizedApproach. Urban Water, 1(4), 323-333.

[7].Konig, K. (2001). The Rainwater TechnologyHandbookRainwater Harvesting in Building, Dortmund, Germany : Wilo-Brain 